\title{
Pendidikan Perdamaian dalam Pembelajaran Sejarah di SMA Jakarta
}

\author{
Firdaus Hadi Santosa, Raka Al Chuza Adnan Kadar, Siti Almaesaroh \\ Pendidikan Sejarah, Fakultas Ilmu Sosial, Universitas Negeri Jakarta \\ Email: firdaushadi@unj.ac.id
}

\begin{abstract}
This article aims to reveal how peace education is conveyed through history lessons at Jakarta Senior High Schools. The research method used in this research is a qualitative research method with a case study approach. The key informants in this study were history teachers and students at SMA Negeri 48 Jakarta and SMA S Cengkareng 1. The results showed that peace education has a correlation with historical education, one of which is material about conflict and peace in history learning. Peace education through historical education is useful for conveying peace values, and can be effectively conveyed in historical lessons. In addition, several things that are obstacles in conveying affective values in history learning are also obstacles to the implementation of peace education in history learning.
\end{abstract}

Keywords: Peace education, history learning, tolerance

\begin{abstract}
Abstrak: Artikel ini bertujuan untuk mengungkapkan bagaimana pendidikan perdamaian disampaikan melalui pembelajaran sejarah di SMA Jakarta. Metode penilitian yang digunakan dalam penelitian adalah metode penelitian kualitatif dengan pendekatan studi kasus. Informan inti dalam penelitian ini adalah guru mata pelajaran sejarah dan para siswa di SMA Negeri 48 Jakarta dan SMA S Cengkareng 1 . Hasil penelitian menunjukkan bahwa pendidikan perdamaian memiliki korelasi dengan pendidikan sejarah, salah satunya adalah dengan materi mengenai konflik dan perdamaian dalam pembelajaran sejarah. Pendidikan perdamaian melalui pendidikan sejarah berguna untuk menyampaiakan nilai-nilai perdamaian, serta secara efektif dapat tersampaikan dalam pembelejaran sejarah. Selain itu beberapa hal yang menjadi hambatan dalam menyampaikan nilai-nilai afektif dalam pembelajaran sejarah juga menjadi hambatan bagi terlaksananya pendidikan perdamaian dalam pembelajaran sejarah.
\end{abstract}

Kata kunci: Pendidikan Perdamaian, Pembelajaran Sejarah, Toleransi.

\section{PENDAHULUAN}

Pembelajaran sejarah pada dasarnya memiliki peran yang penting dalam menyadarkan manusia sebagai makhluk yang menyejarah atau memiliki kesadaran sejarah. Melalui pembelajaran sejarah manusia tidak 
hanya mempelajari fakta-fakta yang telah berlalu saja, melainkan juga mampu mengekstraksi makna yang terdapat dalam setiap fakta tersebut. Kesadaran seajarah setidak-tidaknya berguna agar manusia tidak kembali melakukan kesalahan-kesalahan yang pernah dilakukan di masa lalu, sehingga dalam skala besarnya dapat menghindari terjadinya kembali dosa-dosa atau bencana umat manusia dari masa lalu tersebut (Amboro, 2015). Termasuk di dalamnya yakni konflik-konflik kekerasan yang terjadi baik dalam skala yang besar maupun skala yang kecil yang sama-sama memberikan dampaknya hingga saat ini, sehingga tercipta kehidupan manusia yang penuh dengan kedamaian. Hal ini membuktikan bahwa kesadaran sejarah merupakan hal yang sangat dibutuhkan dalam situasi dan kondisi saat ini yang tengah mengalami kembali penguatan potensipotensi konflik serta kekerasan yang terjadi di mana-mana. Dikarenakan sejarah tidak hanya diwarnai oleh bukti fisik melainkan juga dimensi nilai dan pemikiran, sehingga dapat menumbuhkan karakteristik yang lebih mencintai kedamaian sebagai mana yang ingin dicapai dalam pendidikan perdamaian (peace education).

Sebagai bangsa yang majemuk tentu menjadikan posisi bangsa Indonesia rentan terhadap terjadinya konflik-konflik horizontal. Tanpa adanya kesadaran untuk berkedamaian akan dapat menyebabkan gesekan yang dapat terjadi kapan saja dan di mana saja. Meskipun teori pendidikan perdamaian sendiri lahir dalam rangka mengatasi trauma atas dampak yang terjadi akibat konflik-konflik skala besar seperti Perang Dunia, namun realitasnya perlu juga kesadaran kedamaian dalam lingkup terdekat kehidupan manusia sehari-sehari. Beberapa diantara dari konflik atau kekerasan yang terjadi dapat saja berupa konflik antar kelompok seperti 
tawuran, atau perilaku bullying yang sering kali dianggap sepele tetapi dapat menimbulkan dampak traumatis yang tidak kalah berbahaya. Pendidikan perdamaian memiliki tujuan untuk menumbuhkan pribadipribadi terdidik yang mampu mengantisipasi serta mencegah terjadinya konflik yang dapat mengganggu situasi perdamaian mulai dari lingkungan terdekatnya melalui penanaman pengetahuan, keterampilana serta sikap, ataupun merupakan penggabungan keduanya (Dinn, 2018)(Arslan, Günçavd, \& Polat, 2015).

Sementara pendidikan sejarah serta pembelajaran sejarah juga memiliki tujuan untuk membentuk pribadi yang berkarakter serta memiliki kesadaran sejarah, salah satu yang utamanya adalah agar tidak mengulangi kesalahan yang sebelumnya terjadi atau dilakukan. Selain itu kesadaran sejarah juga diharapkan mampu memberikan jalan berpikir untuk pemecahan suatu persoalan serta menumbuhkan sikap dan kemampuan berpikir kritis. Hal ini menjadi penting mengingat bahwa bahwa materi pendidikan sejarah mampu mengembangkan potensi peserta didik untuk mengenal nilai-nilai bangsa yang diperjuangkan masa lalu, dipertahankan dan disesuaikan untuk kehidupan masa kini, dan dikembangkan untuk kehidupan masa depan (Hasan, 2012). Sehingga pembelajaran sejarah dapat menjadi jalan dalam mempersiapkan kemampuan untuk menghadapi masa depan, sehingga tercipta masa depan yang lebih baik. Pentingnya mempelajari sejarah bagi masa depan terutama agar dapat menentukan tindakan yang tepat guna dalam melanjutkan masa depan sesuai dengan harapan masa lampau (Susanto, 2015).

Secara teoritis keduanya memiliki kesamaan tujuan maupun esensi pendidikan dalam kaitannya membentuk karakteristik pribadi yang lebih 
baik. Mendukung persatuan dan kesatuan serta menghindari jalan konflik atau perselisihan ditengah setiap perbedaan yang dimiliki bangsa ini. Meskipun pada praksisnya para guru sejarah belum tentu menyadari bahwa dirinya telah menerapkan prinsip-prinsip meskipun tidak secara utuh dari pendidikan perdamaian yang dimaksud.

Ironisnya dalam perkembangan politik, kisah dan narasi sejarah makin terbelenggu oleh kekuatan politik yang sempit. Kemerdekaan politik yang dicapai bangsa Indonesia tidak serta merta memberi keleluasaan, keseriusan dan ketulusan dalam menyusun kisah sejarah yang lebih manusiawi. Belajar sejarah yang diharapkan dapat membangun kearifan dan optimisme dalam membangun masa depan sering tergeser oleh jiwajiwa kerdil yang berwawasan sempit. Narasi-narasi sejarah seringkali dijadikan landasan untuk melakukan konflik apabila tidak dibekali dengan pengetahuan dan kesadaran sejarah yang memadai.

Pembahasan mengenai peace education cukup banyak dibahas dalam penelitian-penelitian pada lingkup internasional maupun nasional. Akan tetapi penelitian-penelitian tersebut masih terbatas pada pembelajaran selain pembelajaran sejarah seperti penelitian yang dilakukan oleh Syariatun, dkk. (2019) membahas peace education dalam pembelajaran ilmu sosial, sehingga belum secara spesifik pembahasannya mengenai pembelajaran sejarah. Selain itu penelitian lain juga dilakukan oleh ClarkeHabibi (2018) tentang perpektif guru dalam mendidik untuk perdamaian di Bosnia dan Herzegovina, yang merupakan negara yang sering mengalami konflik. Serta penelitian yang dilakukan oleh Kasherwa (2019) mengenai peran organisasi pemuda dalam membangun perdamaian di kawasan Great Lakes Afrika. Berbeda dari ketiga kajian tersebut penelitian 
ini akan lebih terfokus pada pembelajaran sejarah sebagai salah satu media penerapan peace education. Kebaruan dalam penelitian ini adalah secara mendalam terkait unsur-unsur peace education dalam pembelajaran sejarah sebagai bentuk identifikasi dalam rangka mengembangkan pembelajaran sejarah sebagai salah satu media efektif dalam pelaksanaan peace education.

\section{METODE}

Metode penelitian yang digunakan merupakan metode kualitatif sehingga diharapkan dapat mengungkap berbagai informasi kualitatif dengan deskripsi analisis. Sumber data penelitian adalah para guru mata pelajaran sejarah di SMA Negeri 48 Jakarta dan SMA S Cengkareng 1, serta 30 orang siswa. Pengumpulan data dilakukan melalui teknik wawancara mendalam, observasi non partisipan, serta catatan dokumen. Teknik penentuan dan pengambilan sampe dilakukan dengan menggunakan purposive sampling. Untuk menjamin validitas data yang dikumpulkan, digunakan teknik informant review atau umpan balik dari informan. Teknik analisis data menggunakan model analisis interaktif yang meliputi kegiatan reduksi data, sajian data, verifikasi, dan penarikan kesimpulan. Dalam prosesnya, dilakukan dalam bentuk interaktif sebagai suatu proses yang berlanjut, berulang, dan terus-menerus hingga membentuk sebuah siklus (Huberman, 2014).

\section{HASIL DAN PEMBAHASAN}

\section{Konflik dan Perdamaian dalam Pembelajaran Sejarah}

Konflik dan perdamaian bukanlah istilah yang asing dalam pembelejaran sejarah. Konflik sendiri merupakan bagian dari pembelajaran sejarah yang berkaitan erat dengan peristiwa-peristiwa yang terjadi 
sepanjang perjalanan hidup dan peradaban manusia. Mulai dari konflikkonflik berskala besar seperti perang yang diakibatkan karena perbedaan kepentingan antar negara-negara atau kerajaan, hingga konflik terkecil yang terjadi antar individu di masyarakat. Konflik yang terjadi juga terbagi menjadi konflik vertikal yakni pertentangan penguasa dengan rakyat, seperti yang terjadi dalam Revolusi Perancis, atau juga konflik horizontal yakni pertentangan sesama rakyat, seperti konflik etnis dan perang sipil. Adapun konflik-konflik tersebut dapat dipicu oleh persaingan politik, atau pertentangan-pertangan akibat perbedaan pandangan mengenai suatu hal tertentu.

Sementara itu, perdamaian merupakan antitesis dari konflik yang terjadi, baik sebagai suatu solusi dalam menyelesaikan konflik atau situasi yang tercipta akibat tidak lagi terjadinya konflik. Dalam sejarah suatu konflik hampir selalu diakhriri dengan perdamaian atau setidak-tidaknya perdamaian dapat terwujud setelah suatu konflik dapat teratasi atau terselesaikan. Konsep perdamaian sendiri bisa berupa kesepakatan bersama antar pihak -pihak yang mengalami konflik, atau bisa juga sebagai sebagai sebuah situasi yang terjadi ketika konflik-konflik dapat diatasi atau ditumpas habis, seperti pemberontakan-pemberontakan yang terjadi dalam berbagai peristiwa bersejarah.

Berdasarkan hasil penelitian bahwasanya terdapat suatu pola terkait dengan bagaimana pembelajaran sejarah di SMA Negeri 48 Jakarta dan SMA S Cengkareng 1 menyajikan materi-materi terkait dengan konflik maupun perdamaian tersebut. Setiap materi sejarah hampir selalu terkait dengan konflik atau pun perdamaian, sebagaimana terdapat dalam Kompetensi Inti (KI) dan Kompetensi Dasar (KD) pembelajaran sejarah 
yang secara langsung atau tidak langsung mengandung materi dalam lingkup kedua konsep yang berlawanan tersebut.

Dintaranya terutama pada pembelajaran sejarah Indonesia, pada KD 3.6 dan 3.8 untuk kelas X, KD 3.1 sampai 3.12 untuk kelas XI, serta KD 3. 1 sampai 3.6 untuk kelas XII. Pada pembelajaran sejarah Indonesia di kelas X misalnya, pembahasan mengenai perkembangan kehidupan masyarakat masa kerajaan-kerajaan Hindu dan Buddha, di dalamnya banyak terjadi perselisihan antar kerajaan, seperti Sriwijaya yang berselisih dengan Cholamandala, Singasari, bahkan konflik internal kerajaan tersebut menjelang akhir masa keruntuhannya. Selain itu konflik internal Kerajaan Singasari yang menggambarkan perebutan tahta Ken Angrok dan keturunan-keturunannya, tidak lupa persengketaan antara Kertanegara dengan Kediri. Kemudian pembahasan mengenai Kerajaan Majapahit, yang dalam upayanya menaklukan Nusantara juga mengalami beberapa konflik, setidaknya yang paling umum dibahas adalah konflik Majapahit dengan Kerajaan Sunda dalam Perang Bubat. Begitu juga yang terjadi ketika masa Islam, konflik yang terjadi bahkan sudah melibatkan para pendatang asing dari Eropa. Tentunya pembahasan mengenai konflik dan perdamaian dalam pembelajaran sejarah sangatlah kaya, mengingat dalam peristiwa-peristiwa sejarah konflik dan perdamaian acap kali menjadi sebab musabab terjadinya peristiwa-peristiwa bersejarah tersebut.

Meskipun demikian sebagian besar dari apa yang disampaikan guru dalam pembelajaran sejarah terkait dengan konflik dan perdamaian, belumlah menjadi suatu keharusan, karena belum secara tersurat menjadi kewajiban bagi guru untuk menyampaikan materi tersebut secara khusus mengenai konflik dan perdamaiannya. Akan tetapi hal tersebut lebih 
merupakan suatu upaya dari guru untuk menyampaikan pembelajaran sejarah yang bermakna. Sebagaimana ungkapan dari hasil wawancara berikut:

“..Pelajaran Sejarah itu memberikan gambaran peristiwa - peristiwa pada masa lalu, dan pada masa lalu terdapat konflik yang terjadi. Berarti, pentingnya kita mempelajari hal itu agar kedepannya kita tidak membuat konflik yang sama..." (A. Ardiansyah, wawancara pribadi, 30 Agustus 2020).

Adapun upaya-upaya tersebut tampaknya masih belum maksimal, dikarenakan beberapa masih pada tahap pengenalan (identifikasi) dan penjelasan, belum pada tahap analisis bahkan refleksi. Meskipun dalam beberapa kasus tertentu. Guru berusaha menyampaikan nilai-nilai perdamaian untuk mencapai kebermaknaan dari suatu konflik yang terjadi dalam suatu peristiwa sejarah.

Dalam tahapan perencanaan belum terlihat secara tersirat upaya guru untuk menyampaikan pendidikan perdamaian. Hanya saja, guru melakukan upaya imporvisasi-improvisasi ketika menyampaikan materi mengenai konflik dan peramaian. Hal tersebut misalnya dilakukan dengan mengaitkan materi konflik dan peramaian dengan situasi dan kondisi terkini atau terkait dengan nilai-nilai yang memiliki kedekatan dengan materi yang dipelajari, seperti nasionalisme, toleransi, dan saling menghargai (A. Nurridwan, wawancara pribadi, 07 September 2020).

Adapun upaya guru dalam melaksanakan pembelajaran sejarah terkait dengan kondlik dan perdamaian, dilakukan dengan menggunakan metode pembelajaran yang masih menekankan pada peran serta guru dalam pembelajaran, yakni metode ceramah, diskusi, maupun tanya jawab. Meskipun demikian metode-metode tersebut dirasa lebih efektif dalam menyampaikan pembelajaran yang bermakna, khususnya penanaman 
karakter dan nilai-nilai perdamaian dalam pembelejaran sejarah. Sejauh yang peneliti amati, guru memang masih menggunakan metode-metode yang terbilang masih konvensional tersebut. Adapun salah satu metode yang dapat dijadikan metode alternatif yakni dengan metode pemberian tugas, misalnya dengan memberikan tugas analisis suatu peristiwa konflik dalam sejarah yang kemudian dikaitkan dengan refleksi atau kebermaknaan dari konflik ataupun perdamaian yang terjadi dalam sejarah. Meskipun demikian, keterlibatan guru masih sangat diperlukan guna menjaga siswa agar tidak kehilangan arah dalam memaknai atau menginterpretasi suatu peristiwa sejarah terkait dengan konflik dan perdamaian tersebut.

\section{Pendidikan Perdamaian dan Pendidikan Sejarah}

Pendidikan perdamaian sendiri secara konsep mengacu pada pendidikan yang bertujuan untuk menyampaikan nilai-nilai perdamaian dan resolusi konflik. Selain itu ada juga yang menjadikan perdamaian sebagai suatu bentuk pendidikan karakter, sehingga yang terlihat adalah pendidikan perdamaian sebagai suatu acuan kebijakan dalam hal ini kurikulum, ataukah dalam bentuk lainnya yakni bagian yang termasuk dalam materi pembelajaran tertentu, maupun perpaduan antar keduanya.

Dalam pendidikan sejarah tentunya dapat terlihat bahwa pendidikan perdamaian terwujud dalam bentuknya yang lebih merupakan bagian tidak tersirat dalam pembelajaran (Cydem, 2012). Hal tersebut ditunjukan salah satunya adalah dengan menyampaikan nilai-nilai perdamaian sebagai salah satu upaya untuk menyelesaikan suatu konflik.

Melalui pendidikan sejarah maka diharapkan dapat mencapai tujuan tersebut, dikarenakan pada dasarnya pendidikan perdamaian dan 
pendidikan sejarah juga memiliki tujuan yang sama, yakni pendidikan karakter dan pada akhirnya juga perdamaian termasuk di dalamnya. Selain itu, secara aplikatif pendidikan sejarah dianggap penting dalam mencapai tujuan dan menanamkan nilai-nilai pendidikan perdamaian. Pendidikan sejarah dapat menjadi alat yang efektif untuk menyampaikan tujuan pendidikan perdamaian (Didik, wawancara pribadi, 04 September 2020).

Berdasarkan temuan-temuan hasil penelitian, baik guru maupaun siswa sepakat bahwa pendidikan sejarah lebih efektif dalam menyampaikan nilai perdamaian. Siswa merasa bahwa setelah mempelajari sejarah, menumbuhkan kesadaran untuk saling menghargai dan toleransi, yang tentu saja sangat erat kaitannya dengan perdamaian. Meskipun memiliki keterkaitan yang sangat dekat, namun tidak semua guru sejarah memiliki pandangan yang serupa dalam memandang pendidikan sejarah. Terdapatnya guru-guru yang memiliki anggapan bahwa pendidikan sejarah hanya sebagai pendidikan yang menekankan pada aspek kognitif, sehingga materi yang kemudian disampaikan pun hanya bermaksud memenuhi kewajiban atau target materi semata, serta kurang memperhatikan kebermaknaan dan nilai-nilai yang dapat diambil dari peristiwa-peristiwa yang dipelajari tersebut.

Secara keseluruhan baik pendidikan perdamaian maupun pendidikan sejarah, keduanya memiliki tujuan yang sama yakni salah satunya membentuk karakter saling menghargai, toleransi, dan cinta damai. Dalam pembelajaran sejarah yang lingkupnya adalah mempelajari peristiwa yang sudah berlalu namun dapat memaknainya sebagai pembelajaran untuk kehidupan masa kini, bahkan kehidupan dimasa depan kelak. Tentunya 
pendidikan perdamaian juga memiliki pandangan yang sama, yakni memberikan pemahaman terkait konflik-konflik yang telah lalu atau yang sedang berlangsung agar dapat memaknai dan pada akhirnya mencegah agar konflik tersebut tidak terjadi lagi.

\section{Hambatan Pendidikan Perdamaian dalam Pembelajaran Sejarah}

Dalam pengaplikasian pendidikan perdamaian dalam pembelajaran sejarah, tentunya memiliki beberapa hambatan-hambatan. Beberapa hambatan yang sering dihadapi guru terutama dalam menyampaikan pembelajaran sejarah yang menekankan pada aspek afektif yakni: 1) keterbatasan waktu yang tersedia, dikarenakan materi pembelajaran sejarah yang cukup padat sehingga fleksibilas pembelajaran mengalami keterbatasan; 2) keterbatasan literasi sehingga membatasi kemampuan untuk mengkaitkan antara pembelajaran sejarah dengan kehidupan masa kini terutama terkait dengan isu-isu terkait konflik dan perdamaian; 3) Keterbatasan keterbatasan kemampuan siswa yang membutuhkan upaya tertentu untuk menanamkan nilai-nilai perdamaian dalam pembelajaran sejarah yang bermakna.

Selain itu, hambatan terbesar saat ini yang guru hadapi adalah pelaksanaan pembelajaran daring atau Pembelajaran Jarak Jauh (PJJ). Kondisi pembelajaran yang dilaksanakan melalui PJJ ini tentunya semakin menambah kesulitan bagi guru maupun siswa untuk dapat melaksanakan pembelajaran yang kaya makna. Dikarenakan keterbatasan ruang bagi guru untuk mengekspresikan maksud dan tujuan yang sebetulnya ingin menanamkan aspek afektif dalam pembelajaran sejarah. Namun dikarenakan keterbatasan media yang digunakan dalam pembelajaran, membatasi juga ruang gerak guru untuk melaksanakan tujuan tersebut. 


\section{KESIMPULAN}

Pendidikan perdamaian merupakan salah satu upaya yang dapat dilakukan guru sejarah untuk menyampaikan pembelajaran sejarah yang bermakna. Hal tersebut ditunjukkan dengan banyaknya materi terkait dengan pembahasan mengenai konflik dan perdamaian dalam pembelajaran sejarah, sehingga menjadikan pembelajaran sejarah sebagai alat yang tepat untuk mencapai tujuan pendidikan. Dalam pelaksanaanya pendidikan perdamaian dalam pembelajaran sejarah merupakan bagian yang terintegrasi, yang seringkali digunakan oleh guru sejarah untuk menyampaikan nilai-nilai karakter yang berkaitan dengan perdamaian, diantaranya toleransi dan cinta damai. Meskipun dalam pelaksanaannya menghadapi beberapa hambatan, terutama ketersediaan waktu dalam pembelajran sejarah, namun menjadi sebuah kesadaran yang umum pendidikan perdamaian sangat penting diterapkan dalam pembelajaran sejarah. Sehingga menjadi salah satu upaya untuk mencegah dan menjadi solusi dari setiap konflik, sehingga tercapai perdamaian.

\section{DAFTAR PUSTAKA}

Amboro, K. (2015). Membangun Kesadaran Sejarah Berawal dari Pemahaman. Jurnal HISTORIA, 3(2).

Arslan, Y., Günçavd, G., \& Polat, S. (2015). The impact of peace education programme at university on university students ' intercultural sensitivity. Procedia - Social and Behavioral Sciences, 174, 2301-2307. https://doi.org/10.1016/j.sbspro.2015.01.891

Cydem, E. (2012). The Mission of History Education in Forming Future. Procedia - Social and Behavioral Science, 46.

Dinn, W. (2018). PEACE EDUCATION CURRICULUM IN THE CONTEXT 
OF EDUCATION SUSTAINABLE DEVELOPMENT ( ESD ). Journal of Sustainable Development Education and Research I JSDER, 2(1), 21-32.

Hasan, S. H. (2012). Pendidikan Sejarah untuk memperkuat Pendidikan Karakter. Paramita, 22(1).

Huberman, M. M. . and S. J. (2014). Qualitative Data Analysis, A Methods Sourcebook (3rd ed.). USA: Sage.

Sardiman. (2012). Pembelajaran Sejarah dan Pembangunan Karakter Bangsa, dalam Hansiswany Kamarga dan Yani Kusmarni (Ed), Pendidikan Sejarah Untuk Manusia dan Kemanusiaan: Refleksi Perjalanan Karir Akademik Prof. DR. Said Hamid Hasan, MA. (H. K. dan Y. Kusmarni, Ed.). Jakarta: Bee Media Indonesia.

Sariyatun, Joebagio, H., \& Akhyar, M. (2019). PEACE EDUCATION AS THE DEVELOPMENT OF SOCIAL SKILL IN SOCIAL SCIENCE LEARNING. Paramita: Historical Studies Journal, 29(2), 157-166. https://doi.org/http://dx.doi.org/10.15294/paramita.v29i1.15955

Susanto, H. (2015). Pemahaman Sejarah Daerah dan Persepsi Terhadap Keberagaman Budaya Dalam Membina Sikap Nasionalisme. SEJARAH DAN BUDAYA, 9(1), 39-50. Retrieved from http://journal2.um.ac.id/index.php/sejarah-dan-budaya/article/view/1581 